\title{
AUTHORITARIANISM IN EUROPE INE THE TWENTIETH CENTURY: A POLITICAL-SCIENCE ANALYSIS OF THE CHARACTERISTICS OF THE POLITICAL SYSTEM (PART 2)
}

\begin{abstract}
The article is a political-science analysis of authoritarianism as a political system, which was an alternative to democracy and totalitarianism in Europe in the twentieth century. Three of seven elements of the authoritarian syndrome were analyzed in second part of this article: consolidation of State power; the traditionalist axiological order and its sources; the authoritarian camp. The results of the author's studies presented in the particle show that the collapse of the authoritarian system in Europe in the twentieth century did not stem from the achievement of the declared goals but for two other reasons. First, the defeats suffered during the World War Two caused the breakdown of the authoritarian states in Central Europe, in which the authoritarian order had been established. Regardless of the circumstances, the authoritarian leaders were unable to prevent the loss of independence and of the status of political actor by the states and nations in this part of Europe. Second, in Western Europe (Spain, Portugal, and Greece) there was an internal crisis of the authoritarian political system triggered by the dispute within the ruling camp over the direction of politics and new strategic goals, especially in the face of rivalry between the United States and the Soviet Union under conditions of confrontation between the democratic order and totalitarianism. This was accompanied by the loss of legitimacy by the authoritarian camp, which was tantamount to the delegitimation of the political system.

Keywords: Authoritarianism, Political System, Twentieth Century, Political Thought.
\end{abstract}

\section{LIMITED AUTONOMY OF SOCIETY}

Authoritarian political thought strongly emphasized its negative assessment of public behaviors that occurred in liberal democracy; consequently, only limited autonomy of society was suggested. However, this does not mean consent to the complete incapacitation of society, which was the case under the rule of totalitarian parties.

This feature of authoritarianism was observable on two levels. One was depoliticization or the conscious temporary reduction by State authorities of the scope, extent and form of participation by society and its individual groups in political $\operatorname{life}^{2}$. In

\footnotetext{
${ }^{1}$ Dr hab. prof. UMCS Waldemar Paruch, Wydział Politologii, UMCS w Lublinie, Plac Litewski 3, 20 - 080 Lublin, e-mail: wparuch@o2.pl

${ }^{2}$ The problem of depoliticization was pointed out by: W.T. Kulesza, Koncepcje ideowo-polityczne obozu rzadzacego w Polsce w latach 1926-1935, Wrocław-Warszawa-Kraków-Gdańsk-Łódź 1985, pp. 278, 283; W. Sokół, System autorytarny i jego legitymizacja, [in:] Społeczeństwo Państwo - Władza, ed. M. Żmigrodzki, Lublin 1995, pp. 115-117; idem, Legitymizacja systemów politycznych, Lublin 1997, pp. 73-74.
} 
this respect, authoritarian states differed from democratic and totalitarian ones because a "good" citizen was expected to be passive and law-abiding, and to leave for the State authorities the monopoly of shaping public space. Social activeness was rejected both for practical reasons as generalized experiences gained from democracy, and on ideological grounds.

The new authority, established after the coup, saw depoliticization as a way of reducing social tensions regarded as a factor that paralyzed the democratic State or weakened national unity. At the same time, authoritarian leaders regarded it as a method of achieving a minimum of social reintegration against many factors that sharply divided residents of the State or members of the nation ${ }^{3}$. For the same reason, the perpetrators of an authoritarian coup found the passive attitude of society in political life - (with citizens being active at the same time in the professional, economic, and local-government spheres) - more desirable than the society's involvement as a decisive factor in political struggle. The ruling authoritarian regime did not expect manifestations of social support for its actions, or mass membership of its camp. Nor did it set goals for the society that stemmed from a political wisdom characteristic of totalitarianism, and neither did it make the adoption of the new model of State conditional on social acceptance expressed in elections and referendum. As Juan J. Linz wrote, society was expected only to refrain from public antigovernment activity ${ }^{4}$. By contrast, giving up depoliticization was admissible only in danger, especially external, when the international situation at the stage of crisis justified social mobilization.

The other level is the growing influence of the State on social life ${ }^{5}$, autonomous spheres being maintained. We can regard some of them as extremely important for private and public life.

The first sphere was the market economy independent of ideological goals. However, in comparison with liberal democracy, authoritarian governments adopted a stronger and more determined attitude of interference in the economy. This trend was manifested in restrictions of the freedom of entrepreneurs and free international exchange in the name of the interests of State or nation ${ }^{6}$. Interventionist and etatist measures in the government's economic policy became a standard procedure. The authorities decided that the State should take part in economic processes not only indirectly as their regulator but also in a direct way as a shareholder entity and entrepreneur. These views contained the grounds for expansion of the State sector in the economy. Authoritarian politicians believed that

\footnotetext{
${ }^{3}$ J.J. Linz, An Authoritarian Regime: Spain, [in:] Władza i polityka: wybór tekstów ze wspótczesnej politologii zachodniej, ed. M. Ankwicz, Warsaw 1986, p. 218.

M. Turlejska, Rozmyślania o doktrynie (Próba analizy pojęcia), "Acta Universitatis Wratislaviensis", Historia 1981/36, pp. 435-438; J. Holzer, System faszystowski a autorytarny: Uwagi polemiczne, "Acta Universitatis Wratislaviensis", Studia nad faszyzmem i zbrodniami hitlerowskimi. Faszyzm - teoria i praktyka w Europie (1922-1945) 1977/3, pp. 275-277; J.J. Linz, op. cit., pp. 216-219.

${ }^{5}$ For more see G. Ränki, Państwo i spoleczeństwo w Europie Środkowo-Wschodniej w okresie międzywojennym, "Kwartalnik Historyczny" 1988/4, pp. 180-192.

${ }^{6}$ See P. Łossowski, Rządy dyktatorskie w państwach battyckich 1926-1940: Studium porównawcze, “Acta Universitatis Wratislaviensis", Studia nad faszyzmem i zbrodniami hitlerowskimi 1982/8, p. 24.
} 
State authorities could not shy away from solving economic questions since these were extremely important for the fate of the State and nation. Private ownership had to be protected against all movements that brandished the banner of nationalization or confiscation, but at the same time the satisfaction of social needs at least at the minimum level had to be safeguarded in the way that would prevent the destruction of economic order and discourage the outbreak of a social revolution.

We can assume that the second sphere is the retention of the right to present opposition attitude or to organized opposition. Two model solutions of the opposition problem were adopted in the authoritarian system. In some states the authorities permitted the functioning of opposition parties on condition that these would not actively challenge the existing system. This was the case (with certain temporary exceptions) with Romania (King Carol II and Ion Antonescu), Yugoslavia (King Alexander I and Prime Minister Milan Stojadinović), Lithuania (President Antanas Smetona), Bulgaria (Tsar Boris III) and as well as with Hungary (Regent Horthy) and Poland (Marshal Józef Piłsudski). With regard to other countries we can speak of consent to presenting opposition attitudes reduced to specified ideas and programs, e.g. in Latvia, Estonia, Austria, Greece, Albania, Spain, and in Portugal. However, in no authoritarian state did the opposition, regardless of their scope, extent and organizational forms, have influence on the political activity of the sovereign. His power did not stem from elections nor was it legitimated in this way. That is why all actions of the opposition aimed at the abolishment of this institution, whether through elections or by force, resulted in repressive measures. When the authorities assessed that such a threat appeared, the dictator and his camp used unlawful or extralegal solutions. An example can be the actions taken in Poland by Marshal Piłsudski and his adherents in the following years: 1930 (against the center-left opposition and minority parties), 1933 (against the nationalist opposition), and in 1937 (against the peasant or people's movement). The policy pursued towards the anti-system opposition under authoritarianism can be called "consent for the opposition" because groupings of this type were limited in their capacity as political actors (only some parties were legalized) and in the objective sense (the limited extent and scope of actions). Generally, the opposition posed no threat to the realization of authoritarian political thought and the constant exercise of power. Nor could the attitude of opposition parties be a direct causative factor of system changes because these groupings were not treated as party to ideological and program-related debates.

Under authoritarianism, the independent system of justice preserved its independence of judicial decisions, which were based on legal norms rather than becoming one of the forms of the use of prerogatives by the authority. Consequently, in the authoritarian system the political police did not take over the powers vested in the courts in the field of crime prosecution. A wide private space was also retained outside interference by the State authority.

Furthermore, the catalogue of fundamental civil rights and liberties and a wide space for social initiatives were also maintained. However, civil liberties were not treated as relating to subjects of rights but seen as the content of norms enacted and rationed by the State in accordance with its own interests. An individual was granted rights so that he/she would act for the common interest, especially for the State and/or nation. To make it possible to take such initiatives, plurality of the social communication media was retained, subjected to control by State agencies (censorship) safeguarding the primacy of national, systemic and State interests. This meant an all-out ban on incitement to anti-systemic, 
antinational, and anti-State actions in public speeches, in the press and in other media. Citizens were allowed by the law to form social associations provided these would not be oriented against the values implemented by the sovereign and the State authorities. The social associations were expected to be genuine, self-governing and independent, and their purpose was not to develop political manifestos and political conceptions but to do systematic economic, social, and educational work and create a way of effectively influencing the masses by the State authority. By contrast, no duty to display positive behaviors was imposed on the citizens in respect of propagating ideals, strengthening the political order and supporting the actions of the State authority.

It should be emphasized that these autonomous domains were not treated as the dominant values in political thought, thus they were not entirely exempt from State interference, which intensified in crisis situations if the maintenance of political order required this. The State would implement its tasks concerning social life generally through traditional means (law, education, propaganda, social engineering, moral influence, religious factors) without attributing a decisive role to the apparatus of coercion and terror. Authoritarian political thought specified the motives for broad State intervention; the issue was to restore balance: social balance upset by radical postwar (WWI) reforms that accompanied the establishment of the democratic order; and economic balance disturbed by crises (the post-WWI one in the early 1920s, and the great crisis of the early 1930s).

Authoritarian political thought did not envisage building a new economic and social order. Proponents of authoritarianism believed that the State should be concerned with 1) the protection of borders and security of inhabitants against the external and internal enemy; 2) being responsible for the general interest of the citizens and social hierarchy. They also advanced their own idea of a stable social structure, which can be illustrated with a one-way sequence of relations: the authoritarian sovereign representing State interests $\Rightarrow$ social elite which runs State organs $\Rightarrow$ society organized into institutional social associations $\Rightarrow$ individuals having rights guaranteed by the State. They thereby rejected a policy where the State would carry out a social revolution in order to build a 'new society'. Social advancement could refer only to individuals involved in public service rather than to communities benefiting from decisions taken by the State authorities.

\section{CONSOLIDATION OF STATE POWER}

Military coups were staged under the banner of consolidation of State power through radical political-system reforms, which would consist in the departure from democratic institutions, principles and procedures of exercising State power. The standard was to build the so-called new State, which would take place in two distinct stages: first, practice antidemocratic behaviors, and then formalize the legal rules of the authoritarian State stipulated in the constitution, which was intended to be obeyed and theoretically was.

Before introducing constitutional amendments, the dictator and his followers implemented a new model of politics that would make it possible to reshape public (and private) life. The post-coup-d'état political practice regarded as effective was inspiring in the double sense. First, it became the basis for some provisions contained in the new constitution. Second, it could be invoked under the conditions of a new crisis, also against the new constitution. Through practice and the law the authoritarian camp tried to adjust 
the political system, as they believed, to real possibilities and social relations in such a way that the State and nation would not be threatened in the future by a destructive crisis of the magnitude of another historic disaster. Proponents of authoritarianism were above all interested in the historical permanence of changes rather than in achieving a transitional stage in governing.

By analyzing the legal and political doctrine developed by authoritarian formations we can distinguish the main characteristics of the authoritarian State.

First, authoritarian politicians supported the uniformity of State authority, which meant challenging the tripartite division of powers as an outdated solution regarding the directions of social development and an inefficient one given the existing difficult conditions. However, the accompanying view was that the functions should be divided among several pluralist State bodies which would balance and check one another under the superior and strategic supervision of the dictator.

Second, authoritarian political thought firmly emphasized the need to revise the powers of the parliament. It would cease to be one which appoints the government and supervises its current activities. The role of the representative chambers was to be restricted to five basic responsibilities: 1) legislate constitutional law and statutes fundamental for the political system; 2) represent diverse social attitudes; 3) pass the budget and levy taxes; 4) pass the most important laws concerning foreign policy; 5) assess the work of the government. What remained outside the control of the parliament were both the sovereign's actions and the direct activities of other State bodies, including the armed forces and justice system.

Third, in the authoritarian State the political position of the armed forces was defined in a different way than in the democratic and the totalitarian State. They were recognized as a separate State body subordinated to the sovereign. It was the sovereign that would guarantee the political neutrality of the army separated from typically political bodies (the representative assemblies and the government) and isolated from public opinion and political parties. Such understanding of the political neutrality (apolitical character) of the army meant that on the express order of the sovereign the armed forces might become a factor in safeguarding the interests of State and nation. Depending on the circumstances, military intervention was legitimated at four levels: 1) influencing other State bodies in accordance with constitutional provisions; 2) exertion of pressure by non-legal means on the activity of civil authorities in strategic matters; 3) forcing a reshuffle of the government contrary to constitutional regulations; 4) the overthrow of the civilian constitutional government for the military government. With regard to these actions, the sovereign appeared not only as their inspirer but also an order-giving commander ${ }^{7}$.

Fourth, the aim of military coups was to strengthen and stabilize the government. In the authoritarian state, the appointment and functioning of the government was based on the dictator's trust. The government was thereby made independent of the position expressed by the representative body. Nevertheless, this did not mean that the prime minister and ministers had complete freedom in making executive decisions. The activity of the government and administration was conducted in conformity to constitutional provisions, the budgetary law and the strategic direction laid down by the dictator. The so-

\footnotetext{
${ }^{7}$ W. Sokół, Legitymizacja systemów politycznych..., p. 75.
} 
called directive competence was excluded from the sphere of government decisions; it was reserved directly for the sovereign and covered foreign policy, foreign affairs and the organization of the political-power base of the authoritarian system. Moreover, the dictator, guided by his own identification of political circumstances, could reshuffle the government, which was sometimes fraught with serious policy consequences. In Poland in 1929-1930 Marshal Piłsudski tightened his internal policies, replacing his camp's liberals led by Kazimierz Bartel with a group of colonels. In Hungary, Regent Horthy made a similar turnabout in 1934, replacing the conservatives at the helm of the government with radicals headed by Prime Minister Gyula Gömbös. By contrast, Bulgaria and Lithuania tried to stop radicalism in the actions of their ruling politicians ${ }^{8}$. Tsar Boris III did so in 1929 by dismissing Prime Minister Aleksandar Tsankov and in 1935 by forming the Georgi Kioseivanov government. In Lithuania, President Smetona showed the same attitude by removing Prime Minister Voldemaras from power in 1929.

\section{TRADITIONALIST AXIOLOGICAL ORDER}

Authoritarian formations had their own approach to axiological issues, which was based on two assumptions. First, the cultivated values were to be derived from the history of the State and/or nation and put above the interests of the society living at a given historical time, and placed above the principle of the rule of law. This meant consent to breaking the law for the reasons of State in exceptional circumstances and to forcefully advancing selected values often against the current needs and interests expressed by society. Second, authoritarian camps strove to give the political system a traditionalist axiological order. However, unlike the conservative movement, they sometimes imparted the same content in modernist forms, frequently using revolutionary rhetoric, e.g. this was the case in Spain, Portugal and Poland during the interwar period ${ }^{9}$. A characteristic feature of authoritarian political thought was considerable syncretism and low dogmatism. A manifestation of this approach was two processes: 1) the adoption of numerous conservative, socialist, Christian-Democratic, nationalist or even fascist projects; 2) evolution regarding the proposed concepts and programs, which produced distinct changes in the then current policies.

Authoritarianism assumed the carrying out of considerable changes as compared with the democratic order. Their proponents suggested a departure from the liberal tradition, which was even accused of lacking any values, and that it be replaced by another one based on the conviction that there was an axiological order which was of external (transcendent) origin in relation to an individual, a social group, and contemporary society. György Ränki showed the regularity relating to the consciousness of some of the political elites in interwar Central Europe: while liberalism was useful and helpful in the birth of new states, its principles were not sufficient to strengthen the newly formed state

\footnotetext{
${ }^{8}$ For more on changes of government in Bulgaria and in Lithuania see J. W. Borejsza, Szkoty nienawiści: Historia faszyzmów europejskich 1919-1945, Wrocław-Warszawa-Kraków 2000, pp. 134-135, 142-143.

${ }^{9}$ A. Wielomski, Doktryna El Caudillaje na tle XIX-i XX-wiecznej hiszpańskiej tradycji politycznej, “Acta Universitatis Wratislaviensis", Studia nad faszyzmem i zbrodniami hitlerowskimi 1999/22, p. 172 .
} 
organisms ${ }^{10}$. It was found ineffective to recourse to personal rights and civil liberties under the conditions of many threats, and to the market economy at the time of economic crisis. Instead, the primacy of such values as the State and nation was advanced, which were regarded as the most important political entities/actors in history. Consequently, taking the axiological factor into consideration, we can distinguish in Europe authoritarian regimes with an etatist and nationalist orientation, and eclectic ones. The first group would undoubtedly relate to authoritarian governance exercised in Poland and Austria, in Hungary, Spain, Portugal, Turkey and in Yugoslavia while the second would cover authoritarianism in the Baltic states, in Romania and in Bulgaria.

The sources of the new order were sought primarily in moral norms that derived both from the appropriately interpreted past and from different Christian denominations. Additionally, the sphere of national and State mythologies was invoked, restoring in the historical memory of society the Old Polish period, the concept of the Crown of St. Stephan, the tradition of ancient Roman Dacia, the past of Grand Duchy of Lithuania under the reign of Grand Dukes Olgierd (Algirdas), Gedymin (Gediminas) and Witold (Vytautas), the concepts of Great Serbia, Great Croatia, and Great Bulgaria, and the Franco-inspired idea of hispanidad and instauración (installation) of monarchy ${ }^{11}$.

This determined the shape of authoritarian ideologies, which were not too radical, dogmatic or all-embracing. Nor were they based on political gnosis, but they tried to be symbiotic with the values and morality preached in their teachings by traditional churches. That is why authoritarian political thought was not teleological and did not offer its followers the vision of a new axiological order built on the ruins of the previous heritage. Sometimes the political concepts and programs formulated by the authoritarian camps revealed many religious inspirations, e.g. in Spain, Poland (1935-1939), or in Austria.

For Jerzy Borejsza, authoritarian political thought was a constituent of the history of the European Right. It should be added that in some variants it was rather the conservative Right (Poland, Hungary, Spain), and in some others - it was the more nationalist Right (the Baltic countries) Borejsza formulated another conclusion of cardinal importance for the studies on authoritarianism: the founders of authoritarianism rejected any ideological alliance with the fascists, which in some countries did not exclude cooperation - tactical and highly limited (in terms of duration and scope). Dictators defended traditional rightwing values against the nihilism of the fascist movement perceived as the sister of the communist formation $^{12}$. They did not refer to the factors that divided society such as class or race; instead, they alternately advocated national or State solidarism, often based on a Christian message. There was a general difference between fascism and authoritarian thought: unlike fascists, the leaders and ideologists of authoritarian camps did not set out their goals on a global scale but they made their State and/or nation the sole actors of

\footnotetext{
${ }^{10}$ G. Ränki, op. cit., 180-181.

${ }^{11}$ M. Koźmiński, Nacjonalizm, mniejszości narodowe a reżimy dyktatorskie w Europie ŚrodkowoWschodniej w latach 1918-1939, [in:] Dyktatury w Europie Środkowo-Wschodniej: Konferencja naukowa w Instytucie Historii PAN 2-3 XII 1971, ed. J. Żarnowski, Wrocław-Warszawa-KrakówGdańsk 1973, p. 109.

${ }^{12}$ J. W. Borejsza, Szkoły nienawiści..., pp. 126, 177-178; W.T. Kulesza, op. cit., pp. 269-275; J. Holzer, op. cit., pp. 271-278.
} 
reference in their ideological activity. They wanted to change the order in a specific, actual state whereas they did not intend to form a political camp that would be the carrier of a worldwide vision to be implemented on a universal scale through war as a means of doing politics.

In the political thought of authoritarian camps the axiological order fulfilled four characteristics: it was 1) a system of absolute values, often sanctioned by religion; 2) the result of historical legacy; 3) the effect of activities of successive generations; 4) the public (national/State) interest interpreted then and there and defended by the sovereign. The authoritarian formations described the political arena and the struggle fought in it not in terms of a conflict of reconcilable interests but in terms of opposing values which had to be chosen between.

\section{THE AUTHORITARIAN CAMP}

The authoritarian camp, which exercised power in a political system, organized itself only after a successful coup: consequently, it could not initiate or execute one. This order of events influenced subsequent relations between the authoritarian movement and State administration. The movement not only did not take control of the power apparatus but it also performed an auxiliary function towards it; that is why there was no nomenklatura system in authoritarianism. The authoritarian formation fulfilled the role of the dictator's social and intellectual base to some extent. Nor did the creators of these political entities strive to embrace wide masses of society around them, in which they differed from 1) the communist and fascist movements and from the totalitarian monoparties in the Soviet Union, Italy, and in the Third Reich; and from 2) mass parties, which were the basic political entity in the democratic system during the interwar years. Likewise, authoritarian organizations were not assigned any tasks - not only mobilizing but also indoctrinating ones. Membership in them did not automatically ensure someone's exceptional position in society and not necessarily brought any economic profits since the authoritarian formation did not exploit State resources. Therefore, on the one hand, there was no mass recruitment to the organization, and, on the other hand, no vetting of the members.

The ruling authoritarian formations in the prewar years include: Lithuania - the Tautininkai or the Lithuanian Nationalists Union; Latvia - the Latvian Peasant Union; Estonia - the Fatherland League; Austria - the Fatherland Front; Romania - the National Renaissance Front and the Party of the Nation; Hungary - the Christian National Party, the Smallholders' Party, the Unity Party, the Party of National Unity, and the Party of Hungarian Life; Yugoslavia - the Yugoslav Radical Union and the Yugoslav National Party; Bulgaria - Naroden Sgovor (People's Alliance, National Concord), Demokraticheski Sgovor (Democratic Alliance, Democratic Concord), the 'Zveno' Political Circle; Poland - the BBWR (Non-Party Bloc of Cooperation with the Government), the National Unity [Unification] Camp; Spain - the Spanish Traditionalist Falange; Portugal - the National Union ${ }^{13}$.

${ }^{13}$ P. Łossowski, op. cit., p. 19; A. Wielomski, op. cit., pp. 163-167; P. Machcewicz, Frankizm: Analiza ruchu politycznego, "Magazyn Historyczny. Mówią Wieki" 1990/8, p. 31; J.W. Borejsza, Szkoły nienawiści..., p. 133 et seq.; J. Kochanowski, Weegry: Od ugody do ugody 1867-1990, Warszawa 1997, p. 64 et seq.; P. Skibiński, Państwo generała Franco: Ustrój Hiszpanii w latach 
In the organizational aspect, it should be emphasized that the leaders of authoritarian camps did not attach great significance to the stability of organizational structures - that is why organizational transformations were a general rule and there were authoritarian states, in which the ruling groups did not establish any organization or camps. These chiefs of state were: General Ioannis Metaxas in Greece, Ahmed Zogu in Albania, Karlis Ulmanis in Latvia, and Tsar Boris III in Bulgaria. As Jerzy W. Borejsza observed, the authoritarian camps did not form paramilitary party organizations, which in totalitarianism played an instrumental role in the struggle for power and stabilized both the system and the monoparty ${ }^{14}$.

The foundation for the emergence of an authoritarian formation was a distinct emphasis on the political division into friends and foes, which resulted in the increased polarization, division, and ideologization of participants in political life. The purpose of the sharpness of political divisions was to consciously block cooperation on partnership terms between the authoritarian camp and political parties. In order to distinguish one from another three main criteria were used: 1) the attitude to fundamental values in the authoritarian ideology; 2) assessment of the staged coup d'état; 3) the attitude to the role of the dictator in the system.

The authoritarian movement was not intended to be uniform in terms of organizations and program but all its members had to accept the ideological paradigm, including the model of politics. The dictator's adherents represented different program orientations: they were leftist radicals and liberals as well as conservatives and representatives of the national Right. Most often, they all gathered around the movement's main organization. Reliable examples of programmatic diversity characteristic of authoritarian formations could be the Piłsudski camp in Poland and the Horthy camp in Hungary as well as the Franco movement in Spain. The Polish formation consisted of politicians ranging from socialists (e.g. Leon Wasilewski) to conservatives (e.g. Duke Janusz Radziwiłł), from leftist radicals (for example the circles associated with the reform movement) to rightist radicals (the Piłsudskite colonels' group). A similar politically diverse array can be found around Horthy's adherents - they include both a conservative Istvàn Bethlen and a rightist radical Gyula Gömbös. By contrast, the Franco formation embraced monarchists (the socalled Carlists), the classical republican Right (conservatives, Christian Democrats), and the fascists organized into the Falange (camisas viejas, or old shirts).

Authoritarian formations underwent many organizational changes. However, regardless of the structures, there was a rule, which was best expressed under the Polish conditions by Walery Sławek in his summary of the activities of the BBWR: "the tasks of governing did not fall either on the »camp« or on the Bloc. It was the Government's responsibility" ${ }^{15}$. In Joseph Rothschild's view the Piłsuski formation, like others of this type, consciously professionalized the State apparatus, recruiting the technocratic and

1936-1967, Kraków 2004, passim; idem, Francisco Franco i jego system, "Nowe Państwo", 7 II 1997, no. 6 (63), p. 12; J.H. Saraiva, Krótka historia Portugalii, Kraków 2000, pp. 142-144.

${ }^{14}$ J.W. Borejsza, Mussolini byt pierwszy..., Warszawa 1979, p. 363.

${ }^{15}$ The Archives of New Records, records set of Council of Ministers Presidium, Minutes, $8^{\text {th }}$ sitting, 20 May 1935, k. 444/1; see Biblioteka Narodowa. Zbiory specjalne, W. Zawadzki, "Notatki", vol. 2, k. 2 . 
managerial personnel to replace the "pre-coup" cadres regarded as highly politicized ${ }^{16}$. This approach to the principles of recruitment of administrative personnel slowly and effectively barred the opposition from occupying jobs in the State agencies. Taking into account the typology of party systems, we should say that authoritarian camps always established one-party systems, either of weak or strong type. In one version, other political parties functioned formally and the ruling party did not absolutely dominate the political reality. Such a solution was adopted in Poland and in Hungary. In the other version of one-party system, there was only one authoritarian formation while the remaining parties were dissolved and banned. The strong type of one-party system functioned in authoritarian states like Lithuania, Latvia, Estonia, or Spain ${ }^{17}$. However, when discussing the party system in authoritarianism we should be aware that a constitutive feature of authoritarian political thought was its programmatically anti-party character, that is why the proposition that the authoritarian formation wanted to build any party system sounds heretical. Nevertheless, in objective terms, we reach the conclusion that dictators in fact adopted the version of one-party system in the State.

\section{CONCLUSIONS}

The original plan of the authors of coups was to establish the authoritarian system for a limited period until the internal and external situation calmed down and the main ideological goals were achieved in order to orient the way of thinking of social elites towards values recognized as fundamental in social life and in public space. However, the collapse of the authoritarian system in Europe in the twentieth century did not by any means result from the achievement of those declared goals but for two other reasons. First, the defeats suffered during the World War Two caused the breakdown of the authoritarian states in Central Europe, in which the authoritarian order had been established. Regardless of the circumstances, the authoritarian leaders were unable to prevent the loss of independence and of the status of political actor by the states and nations in this part of Europe. Second, in Western Europe (Spain, Portugal, and Greece) there was an internal crisis of the authoritarian political system triggered by the dispute within the ruling camp over the direction of politics and new strategic goals, especially in the face of rivalry between the United States and the Soviet Union under conditions of confrontation between the democratic order and totalitarianism. This was accompanied by the loss of legitimacy by the authoritarian camp, which was tantamount to the delegitimation of the political system.

\section{LITERATURE:}

[1] Biblioteka Narodowa. Zbiory specjalne, W. Zawadzki, "Notatki”, vol. 2

\footnotetext{
${ }^{16}$ J. Rothschild, East Central Europe between the Two World Wars, Seattle-London 1974, series: "A History of East Central Europe", vol. 9, p. 58.

${ }^{17}$ S.P. Huntington, Social and Institutional Dynamics of One-Party Systems, [in:] Authoritarian Politics in Modern Society: The Dynamics of Established One-Party Systems, eds S.P. Huntington, C.H. Moore, New York-London 1970, pp. 4-7. See P. Łossowski, op. cit., p. 16; A. Wielomski, op. cit., passim.
} 
[2] Borejsza J.W., Szkoły nienawiści: Historia faszyzmów europejskich 1919 1945, Wrocław-Warszawa-Kraków 2000

[3] Borejsza; J.W., Mussolini byt pierwszy..., Warszawa 1979

[4] Holzer J., System faszystowski a autorytarny: Uwagi polemiczne, "Acta Universitatis Wratislaviensis", Studia nad faszyzmem i zbrodniami hitlerowskimi. Faszyzm - teoria i praktyka w Europie (1922-1945) 1977/3, pp. 271-278

[5] Huntington S.P., Social and Institutional Dynamics of One-Party Systems, [in:] Authoritarian Politics in Modern Society: The Dynamics of Established One-Party Systems, eds S.P. Huntington, C.H. Moore, New York-London 1970, pp. 3-47

[6] Kochanowski J., Wegry: Od ugody do ugody 1867-1990, Warszawa 1997

[7] Koźmiński M., Nacjonalizm, mniejszości narodowe a reżimy dyktatorskie w Europie Środkowo-Wschodniej w latach 1918-1939, [in:] Dyktatury w Europie Środkowo-Wschodniej: Konferencja naukowa w Instytucie Historii PAN 2-3 XII 1971, ed. J. Żarnowski, Wrocław-Warszawa-Kraków-Gdańsk 1973, pp. 97-112

[7] Kulesza W.T., Koncepcje ideowo-polityczne obozu rzadzacego w Polsce w latach 1926-1935, Wrocław-Warszawa-Kraków-Gdańsk-Łódź 1985

[8] Linz J.J., An Authoritarian Regime: Spain, [in:] Władza i polityka: wybór tekstów ze współczesnej politologii zachodniej, ed. M. Ankwicz, Warsaw 1986, pp. 215--221

[9] Łossowski P., Rząy dyktatorskie w państwach baltyckich 1926-1940: Studium porównawcze, "Acta Universitatis Wratislaviensis", Studia nad faszyzmem i zbrodniami hitlerowskimi 1982/8, pp. 3-31

[10] Machcewicz P., Frankizm: Analiza ruchu politycznego, "Magazyn Historyczny. Mówią Wieki” 1990/8, pp. 28-33

[11] Ränki G., Państwo i społeczeństwo w Europie Środkowo-Wschodniej $w$ okresie międzywojennym, "Kwartalnik Historyczny" 1988/4, pp. 179-194

[12] Rothschild J., East Central Europe between the Two World Wars, SeattleLondon 1974, series: “A History of East Central Europe", vol. 9

[13] Saraiva; J.H., Krótka historia Portugalii, Kraków 2000

[14] Skibiński P., Francisco Franco i jego system, "Nowe Państwo", 7 II 1997, no. 6 (63), p. 12

[15] Skibiński P., Państwo generała Franco: Ustrój Hiszpanii w latach 19361967, Kraków 2004

[16] Sokół W., Legitymizacja systemów politycznych, Lublin 1997

[17] Sokół W., System autorytarny i jego legitymizacja, [in:] Społeczeństwo Państwo - Władza, ed. M. Żmigrodzki, Lublin 1995, pp. 218-241

[18] The Archives of New Records, records set of Council of Ministers Presidium, Minutes, $8^{\text {th }}$ sitting, 20 May 1935

[19] Turlejska M., Rozmyślania o doktrynie (Próba analizy pojęcia), “Acta Universitatis Wratislaviensis", Historia 1981/36, pp. 433-441

[20] Wielomski A., Doktryna El Caudillaje na tle XIX- $i$ XX-wiecznej hiszpańskiej tradycji politycznej, "Acta Universitatis Wratislaviensis", Studia nad faszyzmem i zbrodniami hitlerowskimi 1999/22, pp. 153-197 


\section{AUTORYTARYZM W EUROPIE W XX WIEKU: POLITOLOGICZNA ANALIZA CECH SYSTEMU POLITYCZNEGO (CZEŚĆ 2)}

Artykuł jest analiza politologiczną autorytaryzmu jako systemu politycznego, alternatywnego dla demokracji i totalitaryzmu w XX wieku. Do tego celu zostało użyte pojęcie „syndrom autorytarny”. Zdefiniowano „syndrom autorytarny”, na który składa się siedem elementów kontytutywnych, występujących łącznie. Elementy zostały wydzielone w wyniku badań źródłowych konkretnych przypadków ustanowienia i funkcjonowania systemu autorytarnego w Europie Środkowej i Zachodniej. Są to: 1) suweren - podstawowa instytucja władzy państwowej; 2) zamach stanu - charakter, typ idealny, cechy charakterystyczne, warianty; 3) formuła legitymizacji władzy państwowej oraz "dramat legitymizacyjny" po śmierci dyktatora; 4) limitowana autonomia społeczeństwa w postaci jego depolityzacji oraz ochrony przed ingerencją państwa wydzielonych sfer życia społecznego; 5) konsolidacja władzy państwowej; 6) tradycyjny ład aksjologiczny; 7) obóz autorytarny. W części 1 artykułu omówiono cztery pierwsze składniki „syndromu autorytarnego". W autorytaryzmie za suwerena uznano państwo, którego interesy i podmiotowość były wyrażane przez dyktatora. Zamach stanu był przeprowadzany przez wojsko bez angażowania społeczeństwa, natomiast formuła legitymizacji władzy państwowej została oparta na roli politycznej i historycznej oraz kompetencjach dyktatora. Celem władzy w autorytaryzmie było zdepolityzowanie najważniejszych konfliktów społecznych i ekonomicznych. W części 2 artykułu omówiono trzy ostatnie składniki "syndromu autorytarnego".

Słowa kluczowe: autorytaryzm, system polityczny, XX wiek, myśl polityczna.

DOI:10.7862/rz.2014.hss.46

Przesłano do redakcji: maj 2014

Przyjęto do druku: październik 2014 